\begin{tabular}{|l|l|l||}
\hline \multicolumn{2}{|c|}{ PublisherInfo } \\
\hline \hline PublisherName & $:$ & BioMed Central \\
\hline \hline PublisherLocation & $:$ & London \\
\hline \hline PublisherImprintName & $:$ & BioMed Central \\
\hline \hline
\end{tabular}

\title{
Release of autoantigens from apoptotic cells
}

\begin{tabular}{||l|l|l||}
\hline \multicolumn{2}{|c||}{ ArticleInfo } \\
\hline \hline ArticleID & $:$ & 38 \\
\hline \hline ArticleDOI & $:$ & $10.1186 /$ ar-1999-66751 \\
\hline \hline ArticleCitationID & $:$ & 66751 \\
\hline \hline ArticleSequenceNumber & $:$ & 34 \\
\hline \hline ArticleCategory & $:$ & Paper Report \\
\hline \hline ArticleFirstPage & $:$ & 1 \\
\hline \hline ArticleLastPage & $:$ & 3 \\
\hline \hline & & RegistrationDate : 1999-11-18 \\
ArticleHistory & $:$ & OnlineDate $:$ 1999-11-18 \\
\hline \hline ArticleCopyright & $:$ & Current Science Ltd1999 \\
\hline \hline ArticleGrants & $:$ & \\
\hline \hline ArticleContext & $:$ & 130752211 \\
\hline \hline
\end{tabular}




\section{Keywords}

Apoptosis, histones, systemic lupus erythematosus

\section{Context}

Autoantibodies found in SLE sera are frequently directed towards antigens exposed during the "blebbing" phase of apoptosis. These blebs contain nucleosomes - DNA wound around a histone core, which have been cleaved by an endonuclease induced by caspases. To investigate the spectrum of autoantibodies to proteins induced by apoptosis in normal human serum and in sera from five patients with SLE.

\section{Significant findings}

Autoantibodies to 13, 21 and $33 \mathrm{kDa}$ antigens were only seen in apoptotic lysates, and at much higher concentrations in SLE sera than in normal controls. These were identified as histone H4 (13 kDa band), $\mathrm{H} 3, \mathrm{H} 2 \mathrm{~b}$ and $\mathrm{H} 2 \mathrm{a}(21 \mathrm{kDa}$ ), and $\mathrm{H} 1 \mathrm{a}$ and $\mathrm{H} 1 \mathrm{~b}$ (33 kDa band). Blocking steps were used to confirm specificity. An immune complex precipitation step ensured that anti-DNA antibodies in DNA/histone complexes were not detected.

\section{Comments}

This finding confirms previous reports of autoantibodies to antigens generated during apoptosis. Since such antibodies were also detected in normal controls, it is suggested that the immune dysregulation of lupus may result from inefficient clearance of apoptotic cells. It would be interesting to confirm the low levels of such antibodies in individual normal subjects (rather than using pooled serum) and also to relate levels of such antibodies to disease activity or manifestations. If poor clearance of apoptotic cells is an important feature of lupus, then methods of enhancing clearance may be of therapeutic importance.

\section{Methods}


Apoptosis was induced in cell lines (Jurkat and U937) using a variety of techniques, and confirmed by both electron microscopy and annexin V/PI staining. Apoptosis-induced proteins were isolated by cell lysis in buffer solutions that preserved cytoplasmic but not nuclear antigens, ultracentrifuged and then electrophoresed. The proteins separated by electrophoresis were blotted onto nitrocellulose and probed with human sera.

\section{References}

1. Huggins ML, Todd I, Cavers MA, Pavuluri SR, Tighe PJ, Powell RJ: Antibodies from systemic lupus erythematosus (SLE) sera define differential release of autoantigens from cell lines undergoing apoptosis. Clin Exp Immunol. 1999, 118: 322-328.

This PDF file was created after publication. 